\title{
The Whereabouts of the Kingdom of God: Countervisualizing the Irish Citizen in Sinn Féin's Editorial Cartoons
}

Mathew Staunton

\section{(2) OpenEdition \\ 1 Journals}

\section{Electronic version}

URL: https://journals.openedition.org/etudesirlandaises/8532

DOI: 10.4000/etudesirlandaises.8532

ISSN: 2259-8863

\section{Publisher}

Presses universitaires de Caen

\section{Printed version}

Date of publication: 31 December 2019

Number of pages: 127-140

ISBN: 978-2-84133-964-8

ISSN: 0183-973X

\section{Electronic reference}

Mathew Staunton, "The Whereabouts of the Kingdom of God: Countervisualizing the Irish Citizen in Sinn Féin's Editorial Cartoons", Études irlandaises [Online], 44-2 | 2019, Online since 06 May 2020, connection on 14 November 2022. URL: http://journals.openedition.org/etudesirlandaises/8532 ; DOI: https://doi.org/10.4000/etudesirlandaises.8532

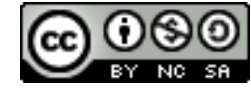

Creative Commons - Attribution-NonCommercial-ShareAlike 4.0 International - CC BY-NC-SA 4.0 https://creativecommons.org/licenses/by-nc-sa/4.0/ 


\title{
The Whereabouts of the Kingdom of God: Countervisualizing the Irish Citizen in Sinn Féin's Editorial Cartoons
}

\begin{abstract}
This article explores the journalistic efforts of the Sinn Féin activists in Arthur Griffith's circle in the period 1909-11 to define Irish citizenship as an active, nation-building duty rather than the relatively passive electoral and financial support demanded by the Irish Parliamentary Party. We will focus on the heroic vision of upright men and women in the propaganda of Robert Lynd and the editorial cartoons of Austin Molloy and tease out the different strands of advice to readers embedded in this rich but overlooked archive.
\end{abstract}

Keywords: Sinn Féin, national identity, editorial cartoons, Ireland, UK, $20^{\text {th }}$ century, citizenship.

Résumé: Cet article explorera les tentatives journalistiques des activistes du Sinn Féin, qui gravitaient autour d'Arthur Griffith dans les années 1909-1911, de définir la citoyenneté plus comme un devoir de construction nationale actif que comme le soutien électoral et financier plutôt passif qu'exigeait l'Irish Parliamentary Party. Nous nous intéresserons plus particulièrement à la vision hérö̈que d'hommes et de femmes intègres que proposent la propagande de Robert Lynd et les dessins éditoriaux d'Austin Molloy et nous tenterons de cerner les différents courants parmi les conseils donnés aux lecteurs qui sillonent cette archive riche mais longtemps négligée.

Mots clés: Sinn Féin, identité nationale, dessins éditoriaux, Irlande, UK, XX siècle, citoyenneté.

Between 1906 and 1914 Arthur Griffith ${ }^{1}$ and a small team of his closest allies ${ }^{2}$ attempted to persuade the readers of their Sinn Féin newspaper that Ireland was "by natural and constitutional right a sovereign state" 3 and was consequently in dire need of its own government. Because this government was not expected to be put in place overnight, most of the resulting propaganda concerned what could be done in the meantime. Aodh de Blácam, a Sinn Féin propagandist himself, sums up Griffith's message in his What Sinn Féin Stands For:

1. Publisher, typesetter and Sinn Féin leader, Arthur Griffith (1871-1922) was an extremely prolific and, perhaps, the most respected propagandist of his generation.

2. This team included Henry Dixon, Seumas MacManus, Denis Devereux, Seán T. Ó Ceallaigh, Thomas Kelly, and Walter Cole, with Robert Lynd contributing from London.

3. Anonymous [but probably Griffith himself], "Constitution of Sinn Féin", in Leabhair na hÉireann, Dublin, Kevin J. Kenny, 1909, p. 260. 
Why wait till Home Rule comes; why wait till the Greek Kalends, Sinn Féin asked, to establish or promote Irish industry? Why not begin now and provide work for our own people at home ${ }^{4}$ ?

The main source for this "Why wait?" propaganda was Griffith's own Sinn Féin Policy, published in $1905^{5}$. This outlines strategies for developing the country using the resources already at the disposal of the Irish people. The members of the Irish Parliamentary Party were relentlessly lampooned in Sinn Féin's propaganda, portrayed as careerist blunderers playing a rigged game badly and wasting precious time. Griffith et al. urged their readers to abandon support for representation at Westminster altogether and redirect all energy into using existing Irish public bodies like the County, Urban and Rural District Councils, the Poor Law Boards, and the Harbour Boards to create a prosperous, virile, and independent nation pending the re-establishment of a national government ${ }^{6}$.

In this illustrated article I will consider how Sinn Féin's textual and visual propaganda explored and defined the notions of national identity and citizenship at a moment in history when nationalists were expected to do little more than vote (if they were entitled to), support their parliamentary representatives and contribute to their operational fund. To this end I will focus on three key editorial cartoons and the contextual discourse in which they were intended to be engaged with.

\section{Mé Féin}

Cautiously refusing to go into detail, the constitution of Sinn Féin organisation mentions that "national self-development through the recognition of the duties and rights of citizenship on the part of the individual" ${ }^{7}$ is vital to Ireland. The ideological framework for this “recognition”, present in embryonic form in Griffith's text, was fully developed by Sinn Féin intellectual Robert Lynd ${ }^{8}$ in his 1907 article "The Ethics

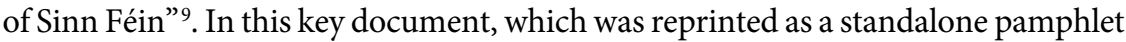

4. Aodh de Blácam, What Sinn Féin Stands For, Dublin, Mellifont Press, 1921, p. 45. The calends or kalends was a feature of the Roman calendar, but it was not included in the Greek calendar. Consequently, to postpone something ad Kalendas Graecas (until the Greek calends) was a colloquial expression for postponing something forever.

5. On 28 November 1905, Griffith presented The Sinn Féin Policy at the first annual convention of the National Council. This is considered by most commentators to be the founding moment of the Sinn Féin organisation.

6. Inspired by Friedrich List's National System of Political Economy, New York, Dry Bones Press, 1999 (first published as Das nationale System der politischen Ökonomie in 1841). It proposes among other things, the reform of the education system, the establishment of national courts of arbitration, and the introduction of a protective system for Irish industries.

7. Anonymous, "Constitution of Sinn Féin", p. 260.

8. Robert Lynd (1879-1949) was a Belfast-born, Presbyterian Sinn Féiner and Gaelic Leaguer and a prolific propagandist for both movements.

9. This text was intended as a sort of handbook for the individual or geographically isolated Sinn Féiner who might not be sure how to best serve the Sinn Féin cause outside of an organisational 
in 1912, Lynd outlines the "Mé Féin Policy" to explain to individual Sinn Féiners the nature of their duties and show how Sinn Féinism could be applied in their daily lives.

Lynd begins by explaining that "the only part of the nation which a good many of us have any chance of setting free immediately is ourselves" ${ }^{10}$ and goes on to stress the inter-dependence of state and individual:

Each of us is the Irish nation in miniature. Therefore, we ought each to make ourselves as like as possible to what we think the Irish nation ought to be. Do you want to deAnglicise Ireland? Well, then the first thing to do is to de-Anglicise yourself. [...] If you wish to see Ireland become a perfect country, a kingdom of God, do you yourself become a perfect individual, a kingdom of God $^{11}$.

The last sentence of this extract is very revealing. Lynd was an Ulster Presbyterian with strong religious beliefs, and in his articles on Sinn Féinism he consistently fuses his Christianity and his nationalism into a single ideology. To ask when Ireland would be free is equated with the Pharisees' question to Jesus in Luke 17:20 about the coming of the kingdom of God. Lynd proposes an answer to the National question based on Jesus's well-known reply:

The kingdom of God cometh not with observation. Neither shall they say, "Lo here!" or, "Lo there!" For, behold, the kingdom of God is within you ${ }^{12}$.

In both cases, what is required is an act of faith on the part of the individual and not the intervention of an external force. For Lynd, this is the essence of Sinn Féinism and he repeatedly comes back to this point in his writings. Looking back at the early Sinn Féin movement in his Ireland a Nation, first published in 1920, he is at his most explicit:

Sinn Féin in the noblest of its aspects is but a Nationalist adaptation of the saying: "the kingdom of heaven is within you." It is founded on the belief that each nation has a sort of "inner light," fidelity to which alone would save it ${ }^{13}$.

Between 1909 and 1911 with emigration figures high and the fate of the Irish language hanging in the balance ${ }^{14}$, Lynd argued that there was a distinct lack of faith in the National idea on the part of the Irish people. In his 1909 article "Sinn Féin and Physical Force" he says:

structure. Similarly to Thoreau's Walden and other transcendentalist texts, it highlighted the importance of integrity, leading by example and leading one's life according to one's principles.

10. Robert Lynd, “The Ethics of Sinn Féin” [1907], in Leabhair na hÉireann, Arthur Griffith (ed.), Dublin, Kevin J. Kenny, 1910, p. 265.

11. Ibid., p. 265-266.

12. Luke 17:20, 21, in The Bible: Authorized King James Version, Robert Carroll, Stephen Prickett (eds.), Oxford, Oxford University Press, 1998.

13. Robert Lynd, Ireland a Nation, New York, Dodd, Mead and Co., 1920, p. 65.

14. The 1911 census figures revealed that, despite enormous enthusiasm and effort, the language movement was failing to make a satisfactory impact on the decline of the Irish language. This was attributed by Sinn Féin propagandists to massive emigration from Irish-speaking areas and an obsession with English culture in urban areas. 
Before you ask these people to fight for an idea, you must make that idea clear and attractive to them. You must make it, as it were, a part of their religion, and I think that Nationalism is a religious idea with only a small minority of the Irish people today ${ }^{15}$.

In the propaganda of both Lynd and Griffith, independence is first and foremost a state of mind rather than a question of state, and achieving it is a matter of faith. Lynd uses more explicitly religious language than Griffith but the message is the same: if you believe that Ireland is independent and you make yourself self-reliant and free, acting like an Irish citizen rather than a British subject, then the administrative structures will simply fall into place.

Sinn Féin propagandists were therefore careful to provide practical instructions for individual nationalists to complement their collective strategy involving the corporations, councils, and boards. While offering numerous examples of similar schemes being operated successfully in other countries ${ }^{16}$, Griffith and his team laid down the ground rules for an alternative lifestyle that would free people from their dependence on English culture and in so doing created the blueprint for the ideal Irish citizen.

\section{Austin Molloy's editorial cartoons}

For the first few years of its existence the circulation of the weekly Sinn Féin was limited. From January 1909 onwards, however, Griffith successfully attracted a broad spectrum of new readers by publishing a daily newspaper with sensational articles from overseas, a fashion column aimed at women readers, and a new graphic approach ${ }^{17}$. The addition of images gave Sinn Féin a far less austere look and significantly improved its commercial appeal, with sales reaching a peak of 64,000 in September $1909^{18}$. Foremost among these images were the large editorial cartoons which regularly appeared on the front page. This user-friendly graphic discourse translated the National question into a series of emotionally charged life and death struggles set against familiar mythical and literary backdrops. At the same time, it illustrated Griffith's instructions to the individual Sinn Féiner, indicating the correct path to follow and the dangers to avoid.

The man responsible for these cartoons was the Dublin-born designer, illustrator, and stained glass artisan Austin V. Molloy. At the age of twenty-two Molloy was hired by the Sinn Féin Printing \& Publishing Company to provide cartoons at a rate of 1 shilling and 6 pence per week. His work appeared in the newspaper between

15. Robert Lynd, "Sinn Féin and Physical Force”, Sinn Féin, 12 June 1909, p. 3.

16. Hungary was always the prime example in Griffith's propaganda but he regularly presented examples of self help and cultural resistance from across Europe and the Americas.

17. Thanks to the acquisition of two brand new Linotype machines, the newspaper became more attractive from a typographical point of view and easier to read.

18. Minute books of the meetings of the board of directors of the Sinn Féin Printing \& Publishing Company, 1906-1914, Dublin, National Library of Ireland, MS 2140. 
August 1909 and April 1911. As was the case for many of the contributors to Sinn Féin, Molloy used the Irish version of his name, Maolmhuidhe, to sign his contributions. It is only by consulting the minutes of meetings of the board of directors of the newspaper company that we can identify him as the Austin Molloy who trained at the Dublin Metropolitan School of Art between 1909 and 1916, at the same time as his more famous friend Harry Clarke. The art historian Theo Snoddy describes him as the "main follower" ${ }^{19}$ of Clarke at the school but, although his illustrations from the 1920s onwards are unmistakably influenced by the work of his friend, his earlier work, which includes his cartoons for Sinn Féin, reveals his debt to the principal book illustrators at the turn of the century, chief among them being Jack B. Yeats.

His cartoons provide us with a snapshot of the issues preoccupying Sinn Féin's propagandists between 1909 and 1911, namely the status of the Irish language, the development of Irish industry, the prevention of emigration and the fate of the Irish Parliamentary Party. Although his training was only beginning, Molloy was already sensitive to the religious and folk themes he would illustrate in books and windows, and the character he chose to represent the ideal citizen of an independent Ireland was inspired by the iconography of Saint Patrick, the Virgin Mary, and The Pilgrim's Progress ${ }^{20}$, and reflects the explicitly religious language of the Sinn Féin propagandist Robert Lynd.

\section{“The National Apostle”}

One of Molloy's most effective cartoons appeared on 19 March 1910 over the caption "The National Apostle" (fig. 1, p. 132). Dressed in a kilt, tweed jacket and cap, this character can be considered Sinn Féin's self-portrait, or to use Lynd's words, as the "Irish Nation in miniature". An exemplary figure, he is reminiscent of Thomas MacDonagh's "Man Upright" ${ }^{21}$, walking confidently up the middle of the street and planting his steps as if each step mattered, demonstrating the duties of the Irish citizen as well as the chief dangers to Ireland's nationhood.

It may surprise the $21^{\text {st }}$-century reader, but at the beginning of the 1900 s Sinn Féin promoted the kilt as the most appropriate costume for Irishmen. There was even a debate among contributors to the newspaper about whether saffron, green, or blue was the most suitable colour and kilts were available for purchase in the Sinn Féin Clothing Company in Dublin ${ }^{22}$. Molloy uses this particular item of

19. Theo Snoddy, Dictionary of Irish Artists: 20 $0^{\text {th }}$ Century, Dublin, Merlin Publishing, 2002, p. 429.

20. The Pilgrim's Progress from This World, to That Which Is to Come is a 1678 Christian allegory written by John Bunyan centering on the protagonist's journey from his hometown, the "City of Destruction" to the "Celestial City" atop Mount Zion.

21. Thomas MacDonagh, “The Man Upright”, accessible in France in Anthologie de la poésie irlandaise $d u X X^{e}$ siècle, Jean-Yves Masson, Pierre-Yves Lambert, Patrick Hersant (eds.), Lagrasse, Verdier, 1996, p. 108-110. Originally published in The Irish Review, vol. 1, no. 4, June 1911, p. 177-178.

22. See Mathew Staunton, "La propagande visuelle du Sinn Féin: comment dessiner la nation", Études irlandaises, no. 26-1, 2001, p. 85. 


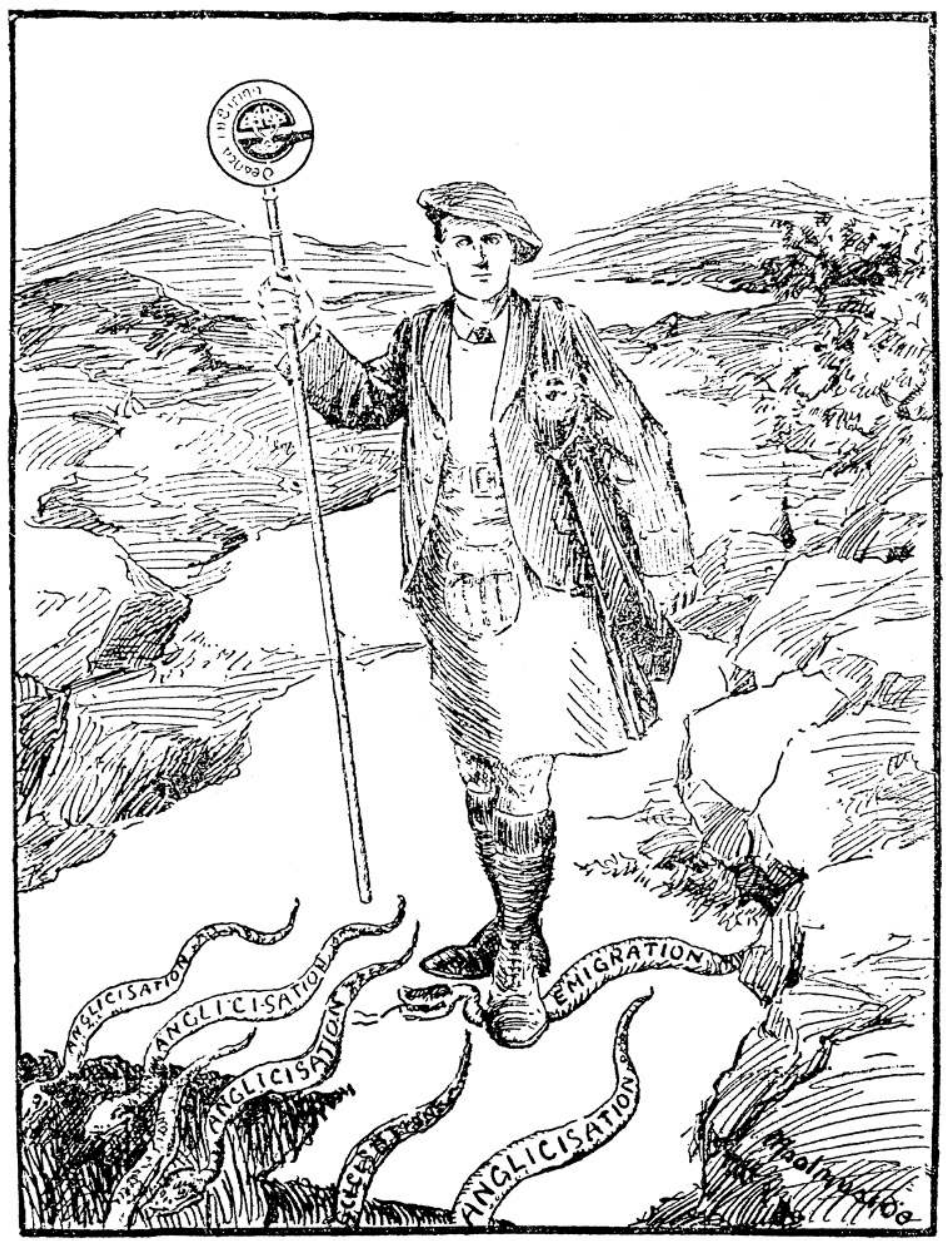

Fig. 1 - Austin Molloy, “The National Apostle”, Sinn Féin, 19 March 1910, p. 1.

clothing to indicate the nationalist politics of his character: to wear an Irish-made kilt in public in 1910 (as a handful of Sinn Féiners did) was to proclaim a distinct Irish identity. In other cartoons this ideal character is contrasted with his less than perfect fellow countrymen, who are defined by their clothes in a similar way. The upper class is represented by a monacle-wearing man in a striped Edwardian suit; the greedy capitalist as a fat man in a three-piece suit and top hat; and the Jewish peddler ${ }^{23}$ as a forlorn-looking character in a ragged suit and battered hat.

Dressed in the true national costume, Molloy's "National Apostle" is the model citizen and represents the values that every reader should aspire to. Like Lynd,

23. In spite of Griffith's inclusive definition of Irishness, Sinn Féin resisted extending it to Jewish people. Readers were encouaged to be skeptical about Jews who claimed to be Irish. 
Molloy sets up an explicit parallel between Sinn Féin and Christianity. The word "apostle" in the caption suggests that this young man's mission is to bring the good word of Sinn Féinism to the people of Ireland, and the unmistakable reference to Saint Patrick in the image equates the Sinn Féin message with that of Ireland's patron saint.

In this case, Patrick's familiar crosier has been replaced by the symbol of the Irish Industrial movement, which consists of an $e$ decorated with a Celtic motif inside a circle with the words Déanta i nÉirinn ("made in Ireland"). Registered by the Irish Industrial Development Association in 1906, this mark (fig. 2, p. 134) could only be displayed on products proven to be 100 per cent Irish made and was very quickly appropriated by Sinn Féin to symbolise its policy of industrial protectionism. In one of his editorials, Griffith explains its importance:

[...] when every Irish person in Ireland knows that whatever does not bear the Irish trademark is not made in Ireland the purchaser will be protected, the manufacturer benefited and the prosperity of the country as a whole be largely increased ${ }^{24}$.

The Sinn Féin newspaper (printed on Irish paper with Irish ink) proudly displayed it in its front page banner. Brandishing the trademark like a talisman, the National Apostle is pictured in the act of crushing a snake labelled "Emigration" which has slithered out onto the road from the right hand side of the image. Six other snakes, all labelled "Anglicisation" are hurrying out of the bottom of the frame. Here, the bulk of Sinn Féin's propaganda at this period has been reduced to a simple formula: buy Irish-made products and stop emigration, and the process of Anglicisation will cease.

It is worth noting that the foot crushing the snake is also reminiscent of Marian iconography. Representations of the Virgin Mary crushing the head of the serpent in the form of statues and the Miraculous Medal would have been very familiar to Irish Catholics. Molloy skilfully fuses the pictorial traditions of these well-known religious figures to reinforce Griffith's anti-emigration propaganda. With this biblical reference he suggests that there is an evil external influence tempting Irish people away to their downfall, but with faith and determination this influence can be eradicated.

In his editorials Griffith identifies this influence as the promotional material directed at Irish people from the United States, Canada, and Australia. In the case of the latter two countries, Sinn Féin writers argued that this was nothing less than government propaganda. Molloy's choice of a snake to represent this propaganda fits into a tradition in political cartoons of depicting the press of one's political enemies as a serpent ${ }^{25}$. Griffith exposed the activities of immigration agents who

24. Arthur Griffith, editorial in Sinn Féin, 17 December 1909, p. 2.

25. John Fergus O'Hea's cartoon "Breasting the Storm”, which appeared in the Weekly Freeman on 23 January 1886, is a good example. The anti-Irish press is represented as a large snake threatening Hibernia as she walks towards College Green, the site of the Irish Parliament before the Act of Union. 


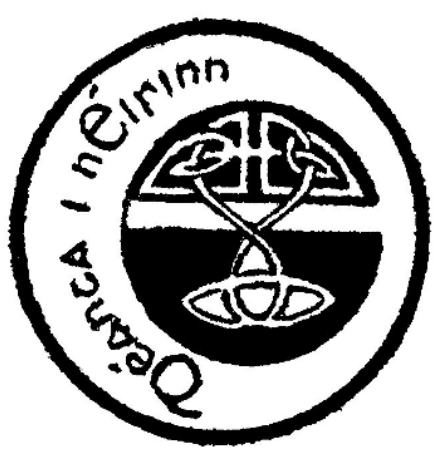

Fig. 2 - The Irish Trademark.

travelled around the country distributing calendars and maps to schools, and placing ads in newspapers. He also called for the boycotting of immigration lecturers who gave public talks about the availability of land and the impressive standard of living in their respective countries. Mr. M. O'Keefe, the immigration lecturer for Queensland, and Mr. G. A. Aylesworth and John Webster, both representatives of the Canadian government, were particularly targeted by Sinn Féin.

Griffith undermined the work of these immigration agents by publishing testimony from unhappy emigrants complaining about false advertising. In April 1910 a man returning to Ireland is reported as saying:

I thought from the encouraging posters and the reports in some papers, which I prove are nothing but lies, that I would make some money. I was feeding a stone crusher, and I had to work my way home ${ }^{26}$.

An emigrant writing from Australia the following year says:

After four years residence in Queensland I cannot find out where the successful Irishmen are. There is little here but poverty and dire poverty. In the name of St Patrick get my countrymen to stay at home and build up their own country ${ }^{27}$.

While attacking all those who promoted emigration, Sinn Féin propagandists used scare tactics to dissuade potential emigrants. Molloy created dramatic images of death mostly drawn from the iconographic tradition of the danse macabre ${ }^{28}$ to illustrate such articles, and we find skeletons, skulls, and grim reapers accompanying the emigrant on his lonely journey. In one of his most striking cartoons Molloy shows emigrants crowding off the docks into the gaping jaws of an enormous skull ${ }^{29}$, but it is clear that those leaving the country cannot see the danger.

26. Sinn Féin, 9 April 1910, p. 1.

27. Sinn Féin, 9 June 1911, p. 1.

28. The danse macabre is an artistic genre of allegory of the Late Middle Ages on the universality of death consisting of a personification of death summoning representatives from all walks of life to dance along to the grave.

29. Sinn Féin, 30 July 1910, p. 1. 
The Sinn Féiner's duty was, therefore, to reveal the truth and convince prospective emigrants to stay at home. Sometimes this involved extreme measures. In both the print propaganda and the images of Molloy, emigration does not only mean death in a figurative sense for Ireland or for the Irish language, but also death in a literal sense for the emigrant himself. In response to Canadian government advertisements promising free land for immigrants to Canada, Molloy shows that the free land does indeed exist but in a frozen wasteland full of wolves ${ }^{30}$. The skeletal remains of the Irish emigrant who took up the offer stand as a warning to anyone else who might be tempted.

\section{"Shapes and Voices"}

A second key cartoon featuring the young man in the kilt appeared in Sinn Féin on 9 April 1910 (fig. 3, p. 136). For the model citizen, nationhood is now in sight but he is surrounded by a group of leprechauns and fairies who encourage him to "turn back" and "trust the British democracy". With this cartoon, Molloy is again illustrating the Sinn Féin propagandists' argument that an act of faith is necessary to achieve independence, but this time in the light of contemporary plates from John Bunyan's The Pilgrim's Progress. The Celestial City, the goal of Bunyan's hero Christian, has been replaced by Sinn Féin's goal of nationhood, and the supernatural figures that line the road give us an idea of the trials and tribulations that the citizen, like Christian, must face before reaching journey's end.

Molloy's reference to The Pilgrim's Progress mirrors Lynd's biblical references and his assertion in his physical force article that "if we burn with a single-minded faith in Ireland, we shall end by making Ireland a free country" ${ }^{31}$. The presence of fairies and leprechauns suggests that the biggest threat to this faith is posed by a superstitious and narrow-minded clinging to old habits. Sinn Féin speakers at public meetings were used to hearing cries of "down with faction" and "stand by the party" from supporters of the Irish Parliamentary Party. This was also the discourse of the newspapers which supported the Party, and so the little figures in Molloy's cartoon serve the same purpose as the snake in figure 1: they represent the counterpropaganda of Sinn Féin's enemies. This propaganda must be ignored if Sinn Féiners are to achieve their objectives, and to illustrate this Molloy shows his hero looking determinedly over the heads of his diminutive detractors towards his destination.

The caption for the cartoon includes a quotation from an "Arabian Tale" which adds a more sinister dimension to these attempts to get the hero to respect the status quo:

And as the youth with much toil ascended the mountain, shapes grew out of the darkness and voices called to him in menace and warning and appeal to him to turn back, but

30. Sinn Féin, 16 October 1909, p. 1.

31. Robert Lynd, "Sinn Féin and Physical Force", p. 3. 


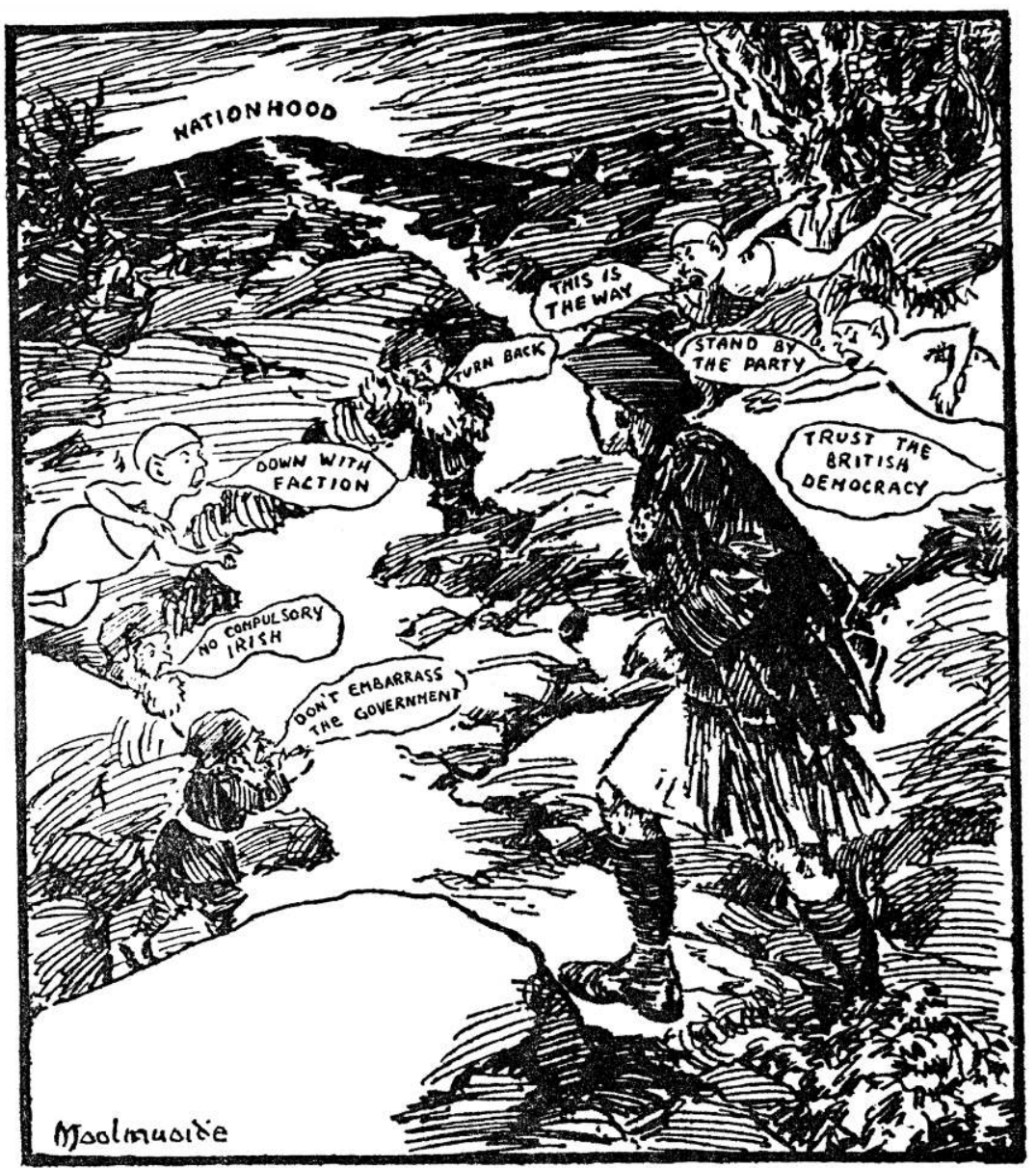

Fig. 3 - Austin Molloy, "Shapes and Voices", Sinn Féin, 9 April 1910, p. 1.

with a great effort he kept onward and turned not his head, for he knew the shapes and voices were those of the evil genii ${ }^{32}$.

The citizen of an independent Ireland must cultivate an inner vision and a penetrating gaze, and trust his own instincts. The snake can be crushed and the leprechauns and fairies can be safely ignored. Faith and determination are the key.

\section{"How the Nation Speaks"}

The cartoon in figure 4, which appeared in Sinn Féin on 28 January 1911, reveals the linguistic identity of the ideal citizen. According to this image he is drawn

32. Sinn Féin, 9 April 1910, p. 1. 


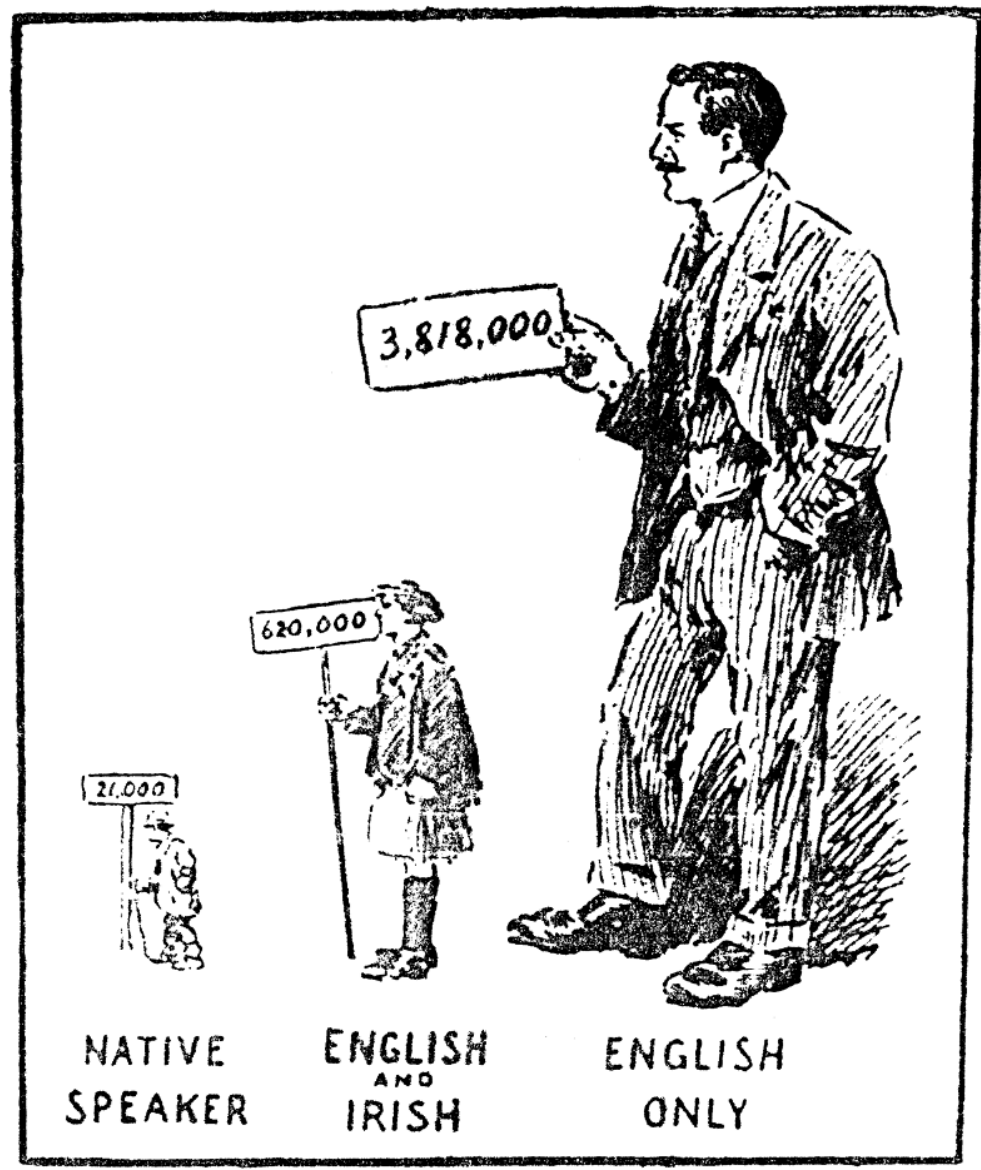

Fig. 4 - Austin Molloy, "How the Nation Speaks”, Sinn Féin, 28 January 1911, p. 1.

from the ranks of the 620,000 speakers of both English and Irish in the country at the time ${ }^{33}$. For Sinn Féin this group represents the shape of things to come and consequently it is at this group that Griffith directs his newspaper propaganda. Griffith's definition of a Sinn Féiner was loose enough to encompass anyone who considered themselves Irish and acted accordingly. How this group was supposed to act was dictated by Sinn Féin, and learning the Irish language was a fundamental necessity. Aodh de Blácam defines the early Sinn Féin movement as "the amorphous propaganda of the Gaelicised young men and women" ${ }^{34}$. His choice of the word "Gaelicised" rather than "Gaelic" is very revealing. The native speakers, always represented in Molloy's drawings by a man in a battered, wide-brimmed hat, a

33. These figures were embarassingly (for the Gaelic League) revealed by the Irish census of 1911.

34. Aodh de Blácam, What Sinn Féin Stands For, p. 45. 
loose-fitting suit with trouser clips and carrying a stick, were not political actors. What they were was a proof of Ireland's nationhood and it was essential that this group be protected. If the native speakers could not be kept in Ireland the principal criterion for nationhood, the possession of a distinct language, would be eliminated.

The middle group was, therefore, encouraged to take an active part in the development of the Irish language. This involved a threefold strategy. Firstly, and most importantly, they were asked to put an end to the emigration of native speakers by helping to develop a more labour-intensive agricultural policy, while building up Irish industry and providing work for everyone. Secondly, they had to reinforce their own Gaelic identity by using whatever Irish they possessed and learning more if possible. Lynd is very clear that this does not involve speaking Irish fluently:

Every word of Irish we speak, every letter we address in Irish is a blow to [English domination in Ireland], a weakening of the foundation of that stronghold. Even if we are too old to hope to ever speak Irish fluently, or if we have not a gift for languages, we can still do something, however little, to make the stock of our thoughts, words, feelings, more Irish and less English than it is, so that we may stand for national, not for foreign, influences ${ }^{35}$.

Thirdly, they were encouraged to transform the largest linguistic group in Ireland, the speakers of English only, represented here by a well-groomed urban character in a three-piece suit, into speakers of both English and Irish. Lynd proposes that the bilingual group lead by example: "One man who learns Irish, however poorly he may succeed in learning it, has a stronger influence on his neighbours than a hundred men who merely advise other people to learn it" ${ }^{36}$. Ultimately this would be achieved by taking control of national education: the ranks of speakers of English and Irish would then swell to over four million, the linguistic criterion in the construction of national identity would be satisfied, and independence would be considerably closer.

Sinn Féinism, especially as defined by Arthur Griffith and Robert Lynd, represented a total political system. The future citizens of an independent Ireland were expected to apply the guidelines laid down by its creators in every aspect of their lives, down to the clothes they wore, the music they listened to, and the products they bought in their local shops. This system was so total that Lynd did not hesitate to describe it as a religion. Austin Molloy, in his own way, also described Sinn Féinism in explicitly religious terms, favouring well-known Christian imagery in his choice of iconographic source material. His ideal citizen is at the same time an apostle, a pilgrim, and a saint, and his choice of models is important. The lives of both Saint Patrick and Bunyan's Christian are undeniable success stories. Both show enormous determination, struggle against adversity, and ultimately reach their goals. The

35. Robert Lynd, “The Ethics of Sinn Féin”, p. 265.

36. Ibid. 
propagandists writing for Sinn Féin asked their readers to do likewise and in so doing echoed the fundamental optimism of Griffith's Sinn Féin Policy, the keystone of the whole movement. In its last paragraph Griffith sums up his message:

It is the duty of a free citzen to live so that his country may be the better for his existence. Let each Irishman do so much and I have no fear for the ultimate triumph of our policy ${ }^{37}$.

Austin Molloy captured the essence of Griffith's free citizen and invested him with the burning faith of Lynd's self-sacrificing apostle to produce the perfect Sinn Féiner. It was up to Sinn Féin's readers to do their best to follow in his footsteps.

\section{Mathew STAUnTON}

Laboratoire de recherche de l'École nationale supérieure des arts décoratifs (ENSADLAB)

\section{Bibliography}

Anonymous, "Constitution of Sinn Féin", in Leabhair na hÉireann, Arthur Griffith (ed.), Dublin, Kevin J. Kenny, 1909, p. 260-263.

Blácam Aodh de, What Sinn Féin Stands For, Dublin, Mellifont Press, 1921.

Bulfin William, Rambles in Éirinn, Dublin, M. H. Gill \& Son, 1929.

Colum Padraic, Arthur Griffith, Dublin, Browne \& Nolan, 1959.

Glandon Virginia E., Arthur Griffith and the Advanced-Nationalist Press: Ireland 19001922, New York, P. Lang, 1985.

Griffith Arthur, “The Sinn Féin Policy” [1905], in The Resurrection of Hungary: A Parallel for Ireland [1904], Dublin, University College Dublin Press, 2003, p. 139-163.

Griffith Arthur, The Sinn Féin Policy, Dublin, J. Duffy (National Council pamphlets), 1907.

Henry Robert Mitchell, The Evolution of Sinn Féin, Dublin, The Talbot Press, 1920.

Laffan Michael, The Resurrection of Ireland: The Sinn Féin Party, 1916-1923, Cambridge, Cambridge university Press, 1999.

Lynd Robert, “The Ethics of Sinn Féin” [1907], in Leabhair na hÉireann, Arthur Griffith (ed.), Dublin, Kevin J. Kenny, 1910, p. 264-272.

MacNamara Brinsley, The Clanking of Chains, Dublin, Maunsel and Co., 1920.

Minute books of the meetings of the board of directors of the Sinn Féin Printing \& Publishing Company, 1906-1914, Dublin, National Library of Ireland, MSS 2138-40.

O’Hegarty Patrick Sarsfield, Sinn Féin: An Illumination, Dublin, Maunsel and Co., 1919.

37. Arthur Griffith, “The Sinn Féin Policy” [1905], in The Resurrection of Hungary: A Parallel for Ireland [1904], Dublin, University College Dublin Press, 2003, p. 163. 
Sinn Féin and Sinn Féin (daily edition), Dublin, Sinn Féin Printing \& Publishing Company, 1906-1914.

Snoddy Theo, Dictionary of Irish Artists: $20^{\text {th }}$ Century, Dublin, Merlin Publishing, 2002.

Staunton Mathew, "La propagande visuelle du Sinn Féin: comment dessiner la nation", Études irlandaises, no. 26-1, 2001, p. 85-99.

Staunton Mathew, "The Nation Speaking to Itself: A History of the Sinn Féin Printing \& Publishing Co. Ltd., 1906-1914", in The Book in Ireland, Jacqueline Genet, Sylvie Mikowski, Fabienne Dabrigeon-Garcier (eds.), Newcastle, Cambridge Scholars Press, 2006, p. 228-245. 